\title{
Strategies for Supply Chain Configurations
}

\author{
Valentina Franchini ${ }^{1}$, João Bastos ${ }^{2}$, Américo Azevedo ${ }^{2}$ \\ ${ }^{1}$ University of Padova, Stradella San Nicola 3, 36100 Vicenza, Italy, franchini@gest.unipd.it \\ ${ }^{2}$ INESC TEC (formely INESC Porto) \& Faculdade de Engenharia da Universidade do Porto \\ Rua Dr Roberto Frias 378, 4200-465 Porto,Portugal, \{joao.bastos,ala\}@fe.up.pt
}

\begin{abstract}
The increasing globalization of the past decades forces the companies to update its supply network strategy in line with the new and challenging context of a competitive market and additional uncertainty. This research, through the development of a model, wants to shed light on which are the most important determinants that influence the supply chain configuration and strategy and how they impact on the performance of the whole supply chain.
\end{abstract}

Keywords

Supply chain configuration; Supply chain strategies; Determinants; Performance.

\section{Introduction}

Over the past decades with the increasing globalization, the industrial enterprises were forced to update its supply network strategy in line with the new and challenging circumstances of a globalized and competitive market. The traditional mass-production paradigm with long life cycles products is changing to small lot sizes production with short life cycles as a norm. As a consequence of the global economic and competitive forces, supply chain managers, are facing additional uncertainty. Thus, company managers have put a growing interest in developing strategies design to provide companies with resources and capabilities in order to compete successfully in the market. This research wants to shed light on which are the most important determinants (factors that influence supply chain strategies' behaviour) that impact on the supply chain configuration and strategy and how they influence on the performance of the whole supply chain. In order to achieve this objective it is proposed a conceptual model depicting the interrelationship between the different determinants and between the determinants and the different supply chain configurations correlating this with the overall supply chain performance.

\section{Supply Chain Strategies}

The concept of supply chain management goes back to pioneering work from Forrester [1958], who identified the dynamics of response to demand changes in supply chains. Forrester have discovered a distortion in demand patterns created by the dynamic complexity present in transferring demand from end users along a chain of supply to manufacturers and material suppliers.

In the end of 20th century, Fisher [1997] figured out that supply chain configuration depends on the type of the product, and in particular he classified two types of product: Functional and Innovative products.

According to his product classification, Fisher has identified two types of supply chain strategies: 
- $\quad$ Efficient supply chain strategy - with the predictable demand of functional products, the market mediation is easy, enabling a nearly perfect match between supply and demand.

- Responsive supply chain strategy - Market mediation costs predominate for these products and they should be manager's primary focus, not physical costs.

Naylor et al. [1997] have proposed the two following definitions:

- $\quad$ Agility means using market knowledge and a virtual corporation to exploit profitable opportunities in a volatile market place.

- Leanness means developing a value stream to eliminate all waste, including time, and to ensure a level schedule.

Starting from these two paradigms, agility and leanness, Naylor et al. [1997] proposes a new hybrid manufacturing paradigm which combines both of the production paradigms and call it "Leagility" as the combination of the lean and agile paradigms within a total supply chain strategy by positioning the decoupling point so as to best suit the need for responding to a volatile demand downstream yet providing level scheduling upstream from the marketplace.

Another researcher, Morash [2001] proposed two major classes of supply chain strategies:

- Operational excellence - endorses business strategies of overall cost leadership through total cost reduction, efficient and reliable supply, and high levels of basic service.

- Customer closeness - supports business strategies of differentiation through high levels of value-added customer service, proactive quality (do it right the first time), and collaborative communications and interactions with customers.

On another work, Lee [2002] proposed a new classification for supply chain strategies in the information age:

- $\quad$ Efficient supply chain - that utilizes strategies aimed at creating the highest cost efficiency in the supply chain.

- $\quad$ Risk-Hedging supply chain - that utilize strategies aimed at pooling and sharing resources in a supply chain so that the risks in supply disruption can also be shared.

- Responsive supply chain - that utilize strategies aimed at being responsive and flexible to the changing and diverse needs of the customers.

- $\quad$ Agile supply chain - that utilize strategies aimed at being responsive and flexible to customer needs, while the risk of supply shortages or disruption are hedged by pooling inventory or other capacity resources.

The authors [Cohen and Roussel 2005] also stat that the supply chain strategy should directly support and drive forward the business strategy which begins with a core strategic vision. This core strategic vision has four primary supply chain competing strategies:

- Competing on Innovation

- $\quad$ Competing on Cost

- $\quad$ Competing on Service

- $\quad$ Competing on Quality

Basing on the work of Gattorna [2010], it is possible to identify four types of supply chain strategies:

- Continuous Replenishment supply chain - this one is quite straight-forward. To work properly, it requires collaboration with customer and suppliers, as simple as that.

- Lean supply chain - lean works well when it fits the value proposition of customers with low cost and efficiency at their front of mind.

- $\quad$ Agile supply chain - this means responsiveness to customers in unpredictable demand situations; it is all about pull.

- $\quad$ Fully Flexible supply chain - this is an extreme example of agile supply chain. 


\begin{tabular}{|c|c|c|}
\hline Authors & Supply Chain Strategy & Characteristics \\
\hline \multirow[t]{2}{*}{ [Fisher, 1997] } & Efficient supply chain & $\begin{array}{ll}- & \text { Functional products } \\
- & \text { Predictable demand } \\
- & \text { Choose suppliers primarily for cost and quality } \\
- & \text { Maximize performance and minimize costs } \\
\end{array}$ \\
\hline & Responsive supply chain & $\begin{array}{ll}- & \text { Innovative products } \\
- & \text { Respond quickly to unpredictable demand } \\
- & \text { Select suppliers primarily for speed, flexibility and quality } \\
- & \text { Use modular design in order to postpone product differentiation } \\
\end{array}$ \\
\hline $\begin{array}{l}\text { [Naylor, Naim et al. } \\
\text { 1999] }\end{array}$ & Lean Supply Chain & $\begin{array}{ll}- & \text { Smooth and predictable demand } \\
- & \text { Elimination of all non-value adding processes } \\
- & \text { Efficient processes } \\
- & \text { Cost minimization } \\
- & \text { Lead time compression } \\
- & \text { Minimum reasonable inventory } \\
\end{array}$ \\
\hline $\begin{array}{l}\text { [Mason-Jones, } \\
\text { Naylor et al. 2000] }\end{array}$ & Agile Supply Chain & $\begin{array}{ll}- & \text { Rapid reconfiguration } \\
- & \text { Flexibility } \\
- & \text { Robustness to variations and disturbances } \\
- & \text { Responsiveness to customers } \\
\end{array}$ \\
\hline $\begin{array}{l}\text { [Christopher and } \\
\text { Towill, 2000] }\end{array}$ & Leagile Supply Chain & $\begin{array}{ll} & \text { Lean paradigm applied to the supply chain upstream from the decoupling } \\
\text { point } & \\
\text { - } & \text { Agile paradigm applied downstream } \\
\text { - } & \text { Decoupling point acts as a buffer }\end{array}$ \\
\hline \multirow{2}{*}{ [Morash 2001] } & Operational Excellence & $\begin{array}{ll}- & \text { Total cost reduction } \\
- & \text { Efficient and reliable supply } \\
- & \text { Standardized products } \\
- & \text { Time-based strategies (JIT) } \\
\end{array}$ \\
\hline & Customer Closeness & $\begin{array}{ll}- & \text { Proactive quality } \\
\text { - } & \text { Value-added customer service and products } \\
- & \text { Collaborative communications and interactions with customers } \\
- & \text { Agility in adjusting supply chain capabilities } \\
\text { - } & \text { Flexibility }\end{array}$ \\
\hline \multirow{4}{*}{ [Lee, 2002] } & Efficient supply chain & $\begin{array}{ll} & \text { Elimination of the non-value-added activities } \\
- & \text { Cost focusing }\end{array}$ \\
\hline & Risk-hedging supply chain & Risk sharing \\
\hline & Responsive supply chain & $\begin{array}{ll}- & \text { Flexibility } \\
- & \text { Build to Order and mass-customization practices }\end{array}$ \\
\hline & Agile supply chain & $\begin{array}{ll} & \text { Flexibility } \\
- & \text { Risk sharing }\end{array}$ \\
\hline \multirow{3}{*}{$\begin{array}{l}\text { [Cigolini, Cozzi et } \\
\quad \text { al. 2004] }\end{array}$} & Efficient supply chain & $\begin{array}{ll} & \text { Commodities products in high volume } \\
- & \text { Stable product flows } \\
- & \text { Improvement focused on operations } \\
- & \text { High level of efficiency and low profit margins } \\
\end{array}$ \\
\hline & Quick supply chain & $\begin{array}{ll}- & \text { Products with unpredictable demand } \\
- & \text { Innovative products } \\
- & \text { Manufacturing flexibility } \\
\end{array}$ \\
\hline & Lean supply chain & $\begin{array}{ll} & \text { Firms compete on price, novelty, quality and customer service } \\
\text { - } & \text { Low costs }\end{array}$ \\
\hline \multirow{4}{*}{$\begin{array}{l}\text { [Cohen and Roussel } \\
\text { 2005] }\end{array}$} & Competing on innovation & $\begin{array}{ll}- & \text { Focus on innovative products } \\
- & \text { Have innovator advantage on price }\end{array}$ \\
\hline & Competing on cost & $\begin{array}{ll}- & \text { Low prices } \\
- & \text { High efficiency and integrated operations } \\
- & \text { Cost minimization }\end{array}$ \\
\hline & Competing on service & $\begin{array}{ll}- & \text { Tailored customer services } \\
\text { - } & \text { Build customer loyalty }\end{array}$ \\
\hline & Competing on quality & $\begin{array}{ll}- & \text { Premium products and services } \\
- & \text { Reliable performance }\end{array}$ \\
\hline \multirow{4}{*}{ [Gattorna 2010] } & Fully flexible & $\begin{array}{l}\text { Unplanned and unplannable demand do to unknown customer with } \\
\text { exceptional, sometimes emergency requests }\end{array}$ \\
\hline & Agile & $\begin{array}{ll}- & \text { Usually unplanned, at least until the last possible moment. } \\
- & \text { Promotions } \\
- & \text { new product launches } \\
- & \text { fashion marketing } \\
- & \text { unplanned stock-outs } \\
\end{array}$ \\
\hline & Lean & 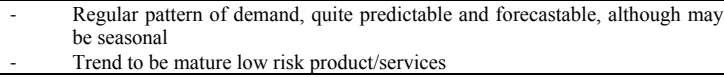 \\
\hline & Continuous Replenishment & $\begin{array}{l}\text { Very predictable demand from known customers } \\
\text { Easily managed through tight collaboration with these collaborative } \\
\text { customers }\end{array}$ \\
\hline
\end{tabular}

Table 1 - Major findings on supply chain strategy

The different kinds of supply chain have been mapped along their performance in order to better identify the overlapping between them (as shown in Table 2). Concerning the performance, and basing on the existent literature, it has been considered the following classification: Flexibility; Time; Costs; Quality; Risk; Innovation; Service. 


\begin{tabular}{|c|c|c|c|c|c|c|c|c|c|c|c|c|c|c|c|}
\hline & 蒂 & 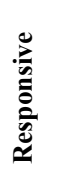 & ฐ్ & 产 & 总 & 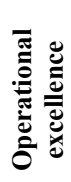 & 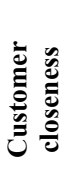 & 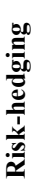 & 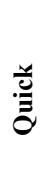 & ة & 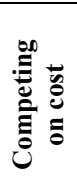 & 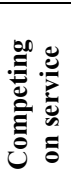 & 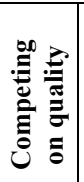 & 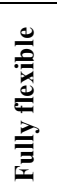 & 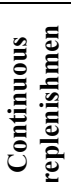 \\
\hline Flexibility & & $\mathrm{X}$ & & $\mathrm{X}$ & & & & & $\mathrm{X}$ & $\mathrm{X}$ & & & & $\mathrm{X}$ & \\
\hline Time & $\mathrm{X}$ & $\mathrm{X}$ & $\mathrm{X}$ & $\mathrm{X}$ & $\mathrm{X}$ & $\mathrm{X}$ & $\mathrm{X}$ & $\mathrm{X}$ & $\mathrm{X}$ & $\mathrm{X}$ & $\mathrm{X}$ & $\mathrm{X}$ & $\mathrm{X}$ & $\mathrm{X}$ & $\mathrm{X}$ \\
\hline Costs & $\mathrm{X}$ & & $\mathrm{X}$ & & $\mathrm{X}$ & $\mathrm{X}$ & $X$ & $\mathrm{X}$ & & & $\mathrm{X}$ & $X$ & $\mathrm{X}$ & & $\mathrm{X}$ \\
\hline Quality & & & $\bar{X}$ & & $\mathrm{X}$ & $\mathrm{X}$ & $\mathrm{X}$ & $\mathrm{X}$ & & & $\mathrm{X}$ & $\mathrm{X}$ & $\mathrm{X}$ & & \\
\hline Risk & & & $\mathrm{x}$ & & & $\mathrm{X}$ & $\mathrm{X}$ & $\mathrm{X}$ & & & $\mathrm{X}$ & & $\mathrm{X}$ & & \\
\hline Innovation & & & & & & & & & & $\mathrm{X}$ & & & & $\mathrm{X}$ & \\
\hline Service & & & & & $\mathrm{X}$ & & & & & $X$ & & $\mathrm{X}$ & & $\mathrm{X}$ & \\
\hline
\end{tabular}

Table 2 - Mapping the supply chain strategies on performance

It could be argue that some types of supply chain strategies overlap other ones and it could be considered only a part of them as the significant ones. The different supply chain strategies have been group together in order to identify which are the most relevant strategies that should be considered.

For the continuation of the study it have been considered the following supply chain strategies as the more representative ones

- Fully Flexible - Competing on innovation

- Agile - Responsive, Quick

- Leagile - Competing on service

- Lean - Operational excellence, Customer closeness, Competing on quality and on cost, Risk-hedging

- Continuous replenishment - Efficient

As proposed by Gattorna [2010] each supply chain strategies have different characteristics; in order to characterized the different supply chain strategies it have been mapped them against the supply chain characteristics proposed by Gattorna (as shown in Table 3).

\begin{tabular}{|c|c|c|c|c|c|}
\hline & $\begin{array}{c}\text { Continuous } \\
\text { replenishment }\end{array}$ & Lean & Leagile & Agile & Fully flexible \\
\hline Production mix & $\begin{array}{l}\text { Mature, branded, and } \\
\text { augmented products }\end{array}$ & $\begin{array}{l}\text { Stable product line; } \\
\text { minimal variant }\end{array}$ & $\begin{array}{l}\text { Larger range; brand } \\
\text { important; product } \\
\text { performance critical }\end{array}$ & $\begin{array}{l}\text { Larger range; brand } \\
\text { important; product } \\
\text { performance critical }\end{array}$ & $\begin{array}{l}\text { Introduce new } \\
\text { product/services on } \\
\text { regular basis }\end{array}$ \\
\hline Innovation emphasis & $\begin{array}{l}\text { Product quality, joint } \\
\text { product development. }\end{array}$ & $\begin{array}{l}\text { Reduce cost of inputs and } \\
\text { processes }\end{array}$ & $\begin{array}{l}\text { Seek product } \\
\text { differentiation }\end{array}$ & $\begin{array}{l}\text { Seek product } \\
\text { differentiation }\end{array}$ & Research and development \\
\hline Marketing emphasis & Build brand loyalty & Lowest price; but reliable & Quick response & Quick response & $\begin{array}{l}\text { Problem-solving } \\
\text { capabilities }\end{array}$ \\
\hline Channel of distribution & $\begin{array}{l}\text { Either direct or via trusted } \\
\text { outlets }\end{array}$ & Wide distribution & $\begin{array}{l}\text { Direct channels to access } \\
\text { consumers }\end{array}$ & $\begin{array}{l}\text { Direct channels to access } \\
\text { consumers }\end{array}$ & Limited, and very targeted \\
\hline Pricing regime & Moderate price sensitivity & Lowest price. EDLP & Moderate price sensitivity & Moderate price sensitivity & No price sensitivity \\
\hline Promotional activity & Low promotional activity & $\begin{array}{l}\text { Low, because margin too } \\
\text { thin }\end{array}$ & $\begin{array}{l}\text { High; fashion-style } \\
\text { approaches }\end{array}$ & $\begin{array}{l}\text { High; fashion-style } \\
\text { approaches }\end{array}$ & Target early adopters \\
\hline Service emphasis & Local customers; trust & $\begin{array}{l}\text { Efficiency and process re- } \\
\text { engineering }\end{array}$ & $\begin{array}{l}\text { Performance to } \\
\text { specification }\end{array}$ & $\begin{array}{l}\text { Performance to } \\
\text { specification }\end{array}$ & Novel solutions \\
\hline $\begin{array}{c}\text { Product/sourcing } \\
\text { approach }\end{array}$ & $\begin{array}{l}\text { Relationships and } \\
\text { capabilities }\end{array}$ & Automatic system & Automatic system & $\begin{array}{l}\text { Market knowledge } \\
\text { capacity }\end{array}$ & Innovative capabilities \\
\hline Production & $\begin{array}{l}\text { Low volume - high value } \\
\text { add. }\end{array}$ & $\begin{array}{l}\text { High volume - low cost; } \\
\text { commodity }\end{array}$ & $\begin{array}{l}\text { High volume - low cost; } \\
\text { commodity }\end{array}$ & $\begin{array}{l}\text { Shorter runs; flexible } \\
\text { scheduling; make-to- } \\
\text { order. }\end{array}$ & Prototypes; customization \\
\hline $\begin{array}{c}\text { Capacities of } \\
\text { consideration }\end{array}$ & Maximum utilization & $\begin{array}{l}\text { High utilization of } \\
\text { existing assets }\end{array}$ & $\begin{array}{l}\text { High utilization of } \\
\text { existing assets }\end{array}$ & Lower utilization & Low. \\
\hline Fulfillment emphasis & Reliable/schedule delivery & High reliability & Short lead-times & Short lead-times & Speed is vital at all times \\
\hline Relationship intensity & Mutual dependence & Low & Low & Low and spasmodic & Intense but short term \\
\hline System/IT support & $\begin{array}{l}\text { Customer management; } \\
\text { CRM }\end{array}$ & Transactional system & Transactional system & Modelling and analysis & Solve the problem \\
\hline $\begin{array}{c}\text { Resource allocation } \\
\text { priority }\end{array}$ & $\begin{array}{l}\text { Supporting the } \\
\text { relationship }\end{array}$ & $\begin{array}{l}\text { Focus on cost reduction at } \\
\text { all times }\end{array}$ & $\begin{array}{l}\text { Focus on cost reduction at } \\
\text { all times }\end{array}$ & Build spare capacity & $\begin{array}{l}\text { Hedge and deploy } \\
\text { resources }\end{array}$ \\
\hline Strategic risk profile & Low & Low & Medium & Higher risk & High \\
\hline
\end{tabular}

Table 3 - Mapping the supply chain strategies on characteristics 


\section{Determinants}

Due to the fact that the definition of an adequate supply chain strategy is a complex task and is dependent on crucial factors, the present study proposed to evaluate which are the main factors (known in the follow as determinants) that determine the supply chain behaviour. So, the main goal of this research is to shed lights on which are the determinants that influence the supply chain configuration and strategy, and which is their impact on the supply chain performance. The following sections present the identified determinants based on research literature and field research.

\subsection{Product Types [Fisher 1997]}

Fisher [1997] classified two type of products:

- Functional products or Commodities - products that satisfy basic needs and don't change much over time, are stable, with predictable demand and long lifecycles. Their stability invites competition, which leads to low profit margins.

- Innovative products or Fashion - products that present innovations in fashion or technology to give customers an additional reason to buy their offerings. Although the innovation enables the company to achieve higher profit margins, the very newness of the products makes the demand unpredictable and their life cycle short.

\subsection{Demand Predictability [Fisher 1997]}

Considering the matrix that Fisher [1997] proposed in his work in order to map the different supply chain strategies it is possible to figure out the second important determinant as demand predictability (low or high).

\subsection{Relationship with customer [Gattorna 2010]}

Basing on the work of Gattorna [2010] it also has been considered the relationship with the customer as one of the most important determinants in the choice of the right supply chain strategy. In fact the authors figured out the strong impact that the customer types have on the supply chain performance.

Gattorna identified four types of customer segments:

- Innovative solutions: unplanned/unplannable demand; require innovative solutions in products and services; low sensitive to price

- Demanding/quick response: rapid response to uneven demand; urgent delivery focus; lower loyality; price aware

- Efficiency/consistency: consistent responses required to largely predictable demands; efficient focus; price sensitive

- Collaborative: close working relationships; mostly predictable demand; relationship focus; loyal

3.4 Supply characteristics - Replenishment lead-time [Lee 2002; Christopher 2006]

Glazner [2006] proposed a classification of the supply chain characteristics classifying them into short lead-time and long lead-time.

In his work, Lee [2002] distinguish between Stable and Evolving supply chains. In this research has been considered the classification of Lee [2002] improving it with the linking to the lead-time:

- Stable supply chain 
- Short lead-time

- Long lead-time

- Evolving supply chain

- Variable lead-time

\subsection{Phase of product life cycle}

Another important aspect to take in consideration, regarding Cigolini's Supply chain strategies definition is connected with the products life-cycle phase. In Figure 1, it is represented the correspondence between the phase of the products life-cycle with the supply chain strategy according to Cigolini's Demand Supply matrix. The phases of the product life cycle considered are: Introduction, Growth, Maturity for complex products (Innovative products), Maturity for simple products (Functional products) and Decline (that has the same behaviour as the Introduction).

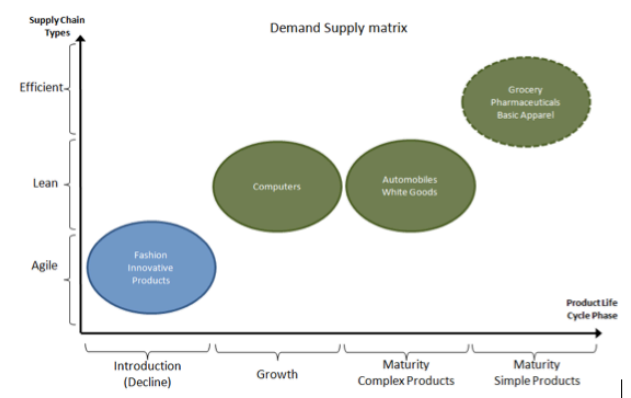

Figure 1 - Phase of product life cycle (based on [Cigolini, Cozzi et al. 2004])

\section{Relationship between the determinants}

Basing on the existing literature on the supply chain strategies (as in chapter 2) it has been proposed a mapping between couple of determinants in order to understand the relations between them.

Figure 2 presents an overall representation of the supply chain strategies listed in Table 1, graphically correlating them with the product typology and demand predictability. In this graph is possible to notice that the Efficient Supply Chain supply chain management strategy from Cigolini [Cigolini, Cozzi et al. 2004] is in a large portion coincident with the Lean Supply Chain strategy, but the difference lies in a mass production approach with emphasis on costs. In contrast, the Lean Supply Chain Strategy approach, also from Cigolini, introduces emphasis equally on product, price, time, service, with increased manufacturing flexibility.

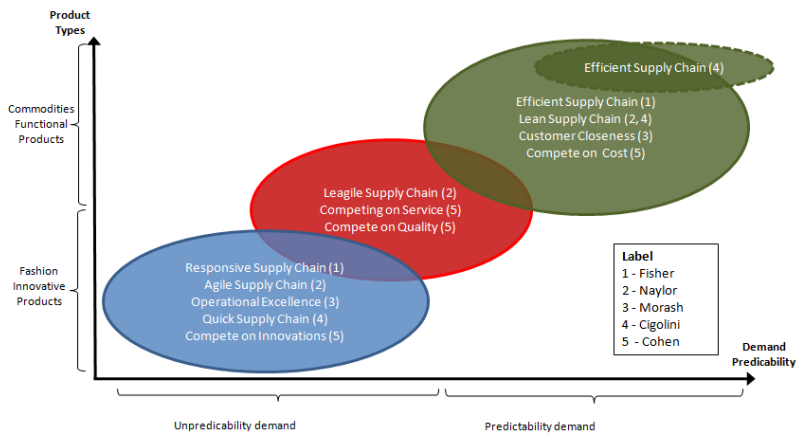


Figure 2 - Supply chain strategy mapped on product types and demand predictability

In both the woks of Fisher [1997] and Lee [2002] the product type has been considered as totally related with the demand characteristic and predictability. Through the model will also be test if this assumption is to be considered correct or not.

Lee [2002] proposed the matrix reported Table 4 where he mapped the supply uncertainty (stable or evolving) with the demand uncertainty (low or high) and he has also argued which are the supply chain strategies that fit in the best way the context generated between these two variables.

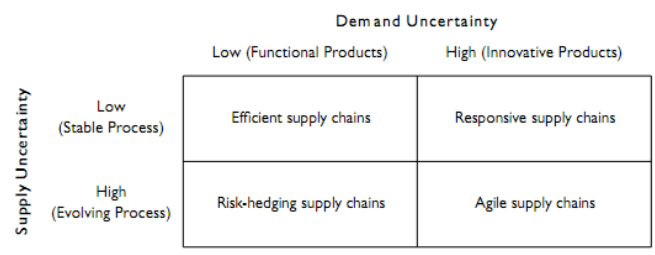

Table 4 - Supply chain strategy mapped on supply uncertainty vs demand uncertainty [Lee 2002]

Christopher et al. [2006] proposed the matrix represented in Figure 6 where there are mapped the supply chain characteristics (long or short lead-time) with the demand predictability.

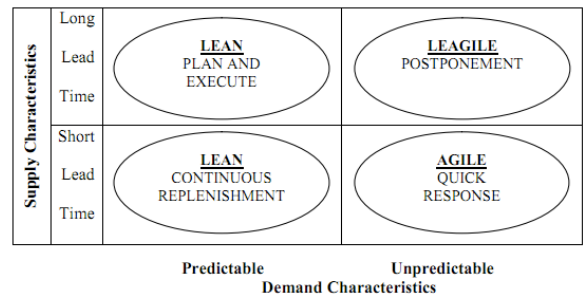

Figure 6 - Supply chain strategy mapped on supply characteristics and demand predictability (based on Christopher et al. [2006])

Basing on the work of $\mathrm{Li}$ and Mao [2008] it is possible to figured out the following matrix where there are considered the product advanced stage and the demand forecasting as the main variables that influence the choice of the supply chain strategy (see Table 5).

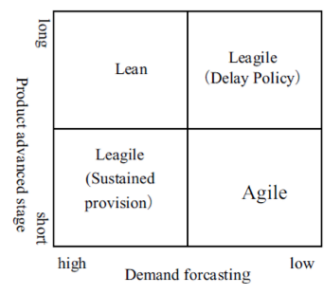

Table 5 - Supply chain strategies mapped along product advanced stage and demand prevision (based on $\mathrm{Li}$, Mao et al. [2008])

Gattorna [2010] proposed a matrix that represent the different supply chain strategies mapped along the predictability of demand and relationship with customer. 


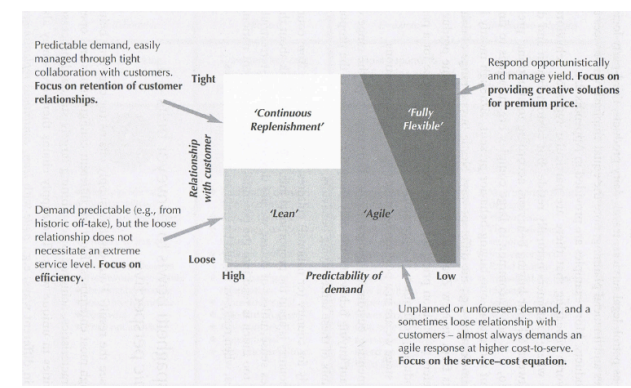

Figure 7 - Supply chain strategies mapped along the predictability of demand and relationship with customer (Gattorna, 2010)

\section{Mediators}

There is also possible to identify some Mediators that could facilitate or not the interaction between the determinants, the supply chain configuration and the performance. The literature review identifies the following four:

- Core Capabilities of the firm and/or supply chain

- Resources of the firm

- Context (Knowledge, ICT, Organizational, Sustainability) of the environment

- Regulation of the environment

\subsection{Core Capabilities}

According to Michael Hugos [Hugos 2006], a major factor that needs to be taking into consideration in the definition of the supply chain strategy involves the definition of the role of each company in the supply chain. These roles are intrinsically related with each company's core competencies. Furthermore, once the company knows what kind of market it serves and the role it will play in the supply chain, it is necessary to develop the supply chain capabilities needed to support the roles of each company according to their core competencies. Hugos argued that these core competencies are essential to guide the decisions made about the five supply chain drivers represented in the Figure 8.

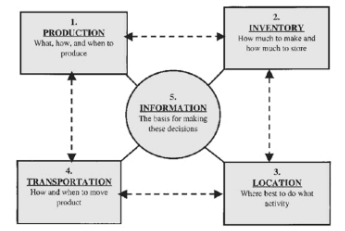

Figure 8 - Major supply chain drivers (based on Hugos [2006])

\subsection{Resources}

The literature review have confirmed that manufacturers consider effective supplier integration as a key factor for achieving or maintaining competitive advantage and they foster supplier integration along the entire value-added chain from development to industrialization [Wagner 2003]. This vertical integration is directly linked with the presence and/or existence of the different resources relevant the specific supply chain functioning as a mediator for the supply chain strategy.

\subsection{Context}

Several research studies have stressed the supply chain context impact in its capability and 
performance. Yuan Niu [2010] in his study has shown the impact of the Information Technology and the Knowledge management in the overall supply chain performance. Also Eltantawy [2005] demonstrated the direct impact of organizational skills on supply chain management performance. More recently Ozcan [2011] have demonstrated the linkage between environmental and sustainability strategies with supply chain vertical integration.

\subsection{Regulation}

Government regulations have a direct impact on the definition of supply chain strategies. For instance, the empirical studies have shown that proactive engagement in sustainable practices lowers the risk of the introduction of new and costly regulations, and proactive engagement in sustainable practices lowers the risk of the introduction of new and costly regulations [Carter and Rogers 2008].

It has been expected that this mediators play a fundamental role and have an impact, that could be positive (as facilitators) or negative, on the relationship between the determinants and the supply chain performance.

\section{Model}

Considering the determinants that has been identified from the literature it was possible to develop a model in which graphically it is possible to represent the relationship between the different determinants and theirs correlation with the supply chain configuration and performance (see Figure 9).

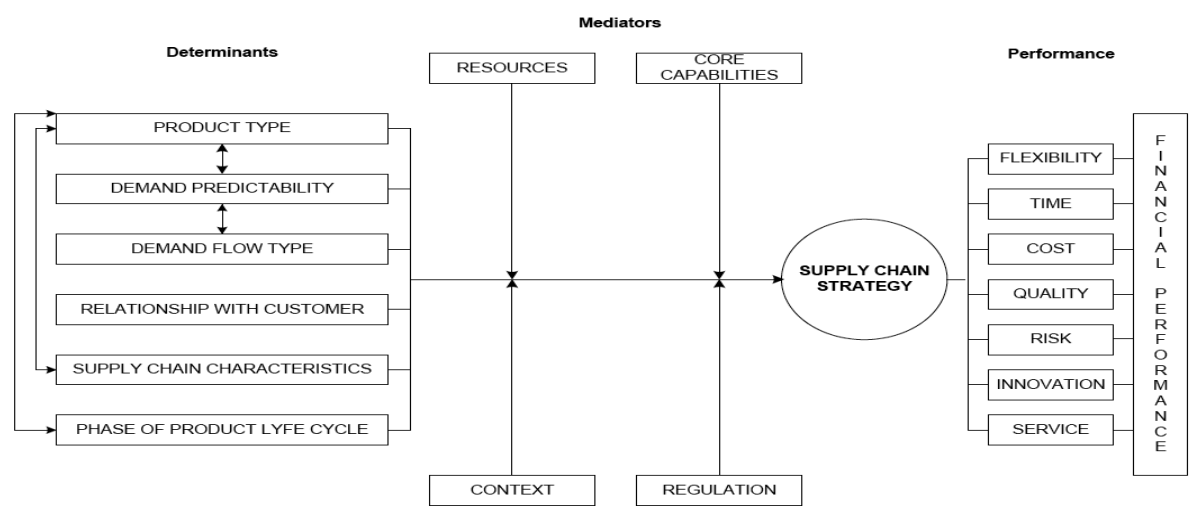

Figure 9 - Supply Chain Strategy Context Diagram

Financial performance of the firm have been taken in account as the most relevant KPI (key performance indicator) in order to evaluate if it has been chosen the best supply chain strategies relating with the determinants and the mediators present in the contextual environment.

\section{Conclusions}

As proposed by Gattorna [2010] it could be possible to configure different supply chain strategies for example depending on the side that we chose to consider. In fact it is therefore important to understand that the alignment with customers and suppliers doe not always work on a linear one-to-one basis. Mixed supply chain combinations are sometimes the best solution, but have to be applied skilfully. The approach used by Gattorna [2010] is 
to specify the demand-side component first, followed by the supply-side component in the overall enterprise supply chain.

The model that has been developed should provide guidelines for the companies in the choice of the best supply chain strategies basing on the contextual environment in order to achieve the better performance relating with the determinants.

Further researches will focus on the testing of the model through a survey that will show the level of interaction between the determinants, the supply chain configuration and the performance. Further work will also test the influence of the mediators in the model.

\section{References}

Carter, C. R. and D. S. Rogers (2008). "A framework of sustainable supply chain management: moving toward new theory." International Journal of Physical Distribution \& Logistics Management 38(5).

Christopher, M. (2000). "The Agile Supply Chain: Competing in Volatile Markets." Industrial Marketing Management 29(1): 37-44.

Christopher, M. and D. R. Towill (2001). "An integrated model for the design of agile supply chains." International Journal of Physical Distribution \& Logistics 31(4): 235-246.

Christopher, M., H. Peck, et al. (2006). "A taxonomy for selecting global supply chain strategies." International Journal of Logistics Management 17(2): 277 - 287.

Cigolini, R., M. Cozzi, et al. (2004). "A new framework for supply chain management - Conceptual model and empirical test." International Journal of Operations \& Production Management 24(1-2): 7-41.

Cohen, S. and J. Roussel (2005). Strategic Supply Chain Management - The five disciplines for top performance. New York, MacGraw-Hill.

Fisher, M. L. (1997). "What Is the Right Supply Chain for Your Product?"Harvard Business Review $105-116$.

Forrester, J. W. (1958). "INDUSTRIAL DYNAMICS." Harvard Business Review 36(4): 37-66.

Gattorna, J. (2010). "Dynamic Supply Chains". Prentice Hall.

Glazner, C. (2006). Enterprise Integration Strategies Across Virtual Extended Enterprise Networks: A Case Study of the F-35 Joint Strike Fighter Program Enterprise. MASTER OF SCIENCE IN TECHNOLOGY AND POLICY.

Hugos, M. (2006). "Essentials of Supply Chain Management." John Willey \& Sons.

Lee, H. L. (2002). "Aligning Supply Chain Strategies with Product Uncertainties." California Management Review 44(3): 105-119.

Lee, H. L. (2004). "THE TRIPLE-A Supply Chain." Harvard Business Review 82(10): 102-112.

Levy, D. L. (1997). "Lean production in an international supply chain." Sloan Management Review 38(2): 94102 .

Li, X. M., Z. F. Mao, et al. (2008). "Study on Manufacturing Supply Chain Leagile Strategy Driven Factors Based on Customer Value." 2008 4th International Conference on Wireless Communications, Networking and Mobile Computing, Vols 1-31: 6948-6951

Mason-Jones, R., M. M. Naim, et al. (1997). "The Impact of Pipeline Control on Supply Chain Dynamics." International Journal of Logistics Management 8(2): 47-62.

Mason-Jones, R., B. Naylor, et al. (2000). "Engineering the leagile supply chain." International Journal of Agile Management Systems 2(1): 54-61.

Mason-Jones, R., B. Naylor, et al. (2000). "Lean, agile or leagile? Matching your supply chain to the marketplace." International Journal of Production Research 38(17): 4061-4070.

Mason-Jones, R. and D. R. Towill (1999). "Total cycle time compression and the agile supply chain." International journal of production economics 62(1-2).

Morash, E. A. (2001). "Supply Chain Strategies, Capabilities, and Performance." Transportation Journal 41(1): 37.

Naylor, J. B., M. M. Naim, et al. (1999). "Leagility: Integrating the lean and agile manufacturing paradigms in the total supply chain." International Journal of Production Economics 62(1-2): 107-118.

Niu, Y. (2010). The impact of information technology on supply chain performance: A knowledge management perspective. PhD, University of North Carolina at Charlotte.

Ozcan, O. (2011). "The impact of supply chain and network structure on the environmental performance of sustainability-focued companies". PhD University of South Florida.

Wagner, S. M. (2003). "Intensity and Managerial Scope of Supplier Integration." Journal of Supply Chain Management 39(4): 4-15. 